American Journal of Environmental Sciences 5 (1): 116-123, 2009

ISSN 1553-345X

(C) 2009 Science Publications

\title{
Vegetation Dynamics Depending on Ecological Particularities of Bozanta Mare (Maramures County-Romania) Tailing Pound: Case Study
}

\author{
${ }^{1}$ Monica Marian, ${ }^{1}$ Leonard Mihaly Cozmuta, ${ }^{1}$ Camelia Varga, \\ ${ }^{1}$ Anca Mihaly Cozmuta and ${ }^{2}$ Eugen Nour \\ ${ }^{1}$ Faculty of Science, North University of Baia Mare, No. 76 Victoriei Road, Baia Mare, Romania \\ ${ }^{2}$ Inspectorate for Emergency Situations, Baia Mare, Romania
}

\begin{abstract}
The present study followed an ecological demarche of reintegration in the scenary through revegetation of an anthropic ground, consisting in a waste pond formed from the flotation activity of non-ferrous ores. Problem statement: To support the formation of a compact vegetal layer, having anti-erosion and a restoration role, a preliminary study was required regarding the spontaneous settlement of different vegetal species. We had followed the specific floristic composition and biodiversity on the waste pond, manner of association of plant species and possible interactions with other species from the biocenosis (microorganisms and fungi). We had studied the pace at which vegetal species settle, as well as the reciprocal influence, from the point of view of vegetation, with the neighboring area, since the desideratum was the settlement of a vegetation similar to the natural one. Approach: The aim of the research was to draw a list of the vegetal taxa installed on the pond, as well as to detect some succession stages or some possible vegetal associations. We had established the share of different species in the vegetal layer on the waste pond through an analysis of ecological preferences, of the geographical origin of plant species, of the cariological and bioform profile. All this was done to compare the possible vegetal associations which settle on such anthropic grounds with the neighboring vegetation. The approach used was the classical one in fitosociology, recommended by the central European fit sociological school adapted to the pedo-climatic conditions in Romania. Results: Over 50 species of plants and fungi spontaneously settled had been listed and we had followed their association as well as their distribution, compared to the microclimatic conditions of the waste pond. We had distinguished species with a large potential of revegetating highly polluted with heavy metals waste ponds and sites. Conclusion/Recommendations: Starting from this study, we may establish a formula of sustaining the vegetation and using the interactions among species in order to stimulate the settlement of dense vegetation, which might ensure anti-erosion protection and landscape integration.
\end{abstract}

Key words: Tailing ponds vegetation, biological rehabilitation

\section{INTRODUCTION}

Non-ferrous minerals represent an important economic resource for most European States. The amount of ore processed by the mining industry each year is about 60 billion tons, of which waste accounts for almost 55\%. Disposing of such enormous quantities of waste is a challenge for the mining industry and the issue is of concern to both authorities and citizens. Depending on the naure of the waste generated by mining activities, two methods to dispose of it generally apply. The discharge as tailings waste applies to the coarser particles coming from mine opening activities and they generally have no economic value. The fine particles resulted from mineral processing are mixed with water and deposited in the form of slurry in tailings ponds. The construction does not always take place in compliance with safety requirements and this poses a high level of risk in countries where safety recommendations are not strictly followed. Tailing ponds are constructed without any impervious core and, as such, process and rainfall water seep through the dam towards its free face. Uncontrolled water flowing through, beneath or - in the worst case - over the dam can lead to a loss of stability. Water management is a key safety factor for the handling of large amounts of heterogeneous wet slurries. One of the main causes of accidents and hazards in tailing facilities is lack of

Corresponding Author: Monica Marian, Faculty of Science, North University of Baia Mare, Victoriei str. 76, Baia Mare, Romania 
water management practices. Failure and collapse of tailings ponds has tremendous consequences including casualties, damage to property and pollution of the environment. Many studies have reported the impacts and risk factors of failure of tailings wastes and tailings ponds on surrounding environment ${ }^{[1-4]}$.

Study area: In Maramures County, in the hot spot areas of non-ferrous mining industry are located over 20 tailing ponds, many of them still active. We can notice a special situation near Baia Mare city, where, in the same area, there are three tailing ponds (Fig. 1), one of them being under preservation.

The Preserved Tailings Pond is the oldest in the area and has been under preservation for more than 20 years.

The Remin Tailing Pond which was built in 1977 covers $1,050,000 \mathrm{~m}^{2}$, is $30 \mathrm{~m}$ deep and has an embankment of $18-20^{\circ}$. Hydrocyclones located on the wall of the pond mechanically purify the wastewater collected from the industrial plants of Baia Mare. The pond collects the liquid phase thus spilled and the solid waste is deposited on the wall for reinforcement purposes. A build-up rate of $2 \mathrm{~m}^{\text {annum }}{ }^{-1}$ has allowed for over $150,000,000 \mathrm{~m}^{3}$ of tailings to accumulate in the pond. Winds easily transport the dam's fine particles. There were a few attempts to consolidate the pond by planting trees of which bur (Cirsium lacceolatum) and acacia (Robinia pseudaccacia) are best adapted to the site.

The newest pond in the area is the Transgold Tailings Pond, where the wastewaters coming from the Transgold Plant (former AURUL) used to be discharged. The pond which is about $3.8 \mathrm{~km}$ long and covers $94,0000 \mathrm{~m}^{2}$ contains wastewaters with high amounts of heavy metals and cyanide.

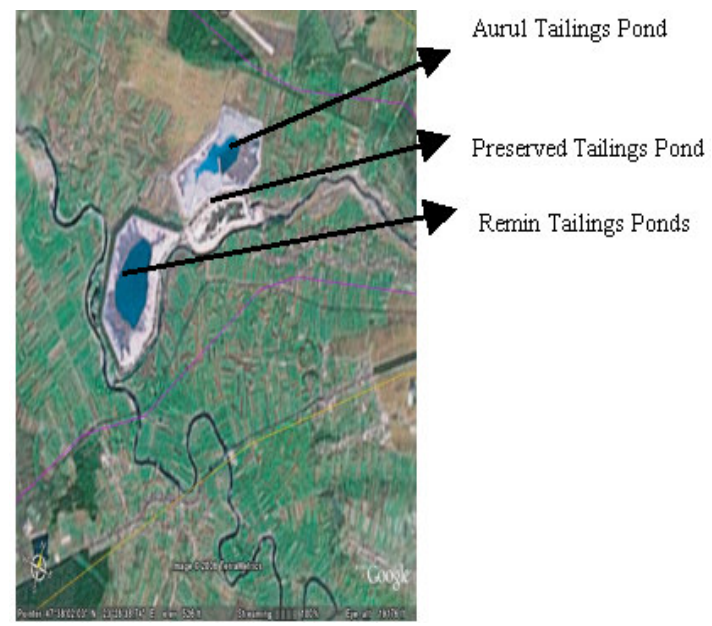

Fig. 1: Overview of tailings ponds in studied area
The study considers preserved tailings pond: The physical stability of dam refers to the collapse of the dam as a consequence of circular sliding, sinking of the foundation and regressive erosion induced by the spilling of the wastewater over the dam. The main factors which influence the physical stability of the dam are the granulometry of the grains, the construction characteristics, the sesismic risk of area, the configuration of the tailing's foundation and also its physical, chemical and elastic properties. For the Preserved Tailings Pond, the physical characteristics of the soils are shown in Table $1^{[5-8]}$.

Due the fact that the largest part (about 39\%) of pond's dam is made by fine particles (under $0.005 \mathrm{~mm}$ Table 1), large amounts of fine particles in the sublayer, strongly polluted with heavy metals, were transported by winds and deposited in the surrounding areas. Large size particles were transported by rains and thus many ravines appeared Fig. 2. This erosion process reduces the physically stability of the pond.

Chemical stability of the tailing pond and the soil around is strongly affected by the potential acidity of the solid waste forming the dam. Pyrite $\left(\mathrm{FeS}_{2}\right)$ accounts for the highest proportion of the chemical composition in the above-mentioned tailing ponds with chalcopyrite $\left(\mathrm{CuFeS}_{2}\right)$, galena $(\mathrm{PbS})$ and sphalerite $(\mathrm{ZnS})$ being reported as well.

\begin{tabular}{|c|c|c|}
\hline Nr. Crt. & Parameter & Value \\
\hline 1 & Texture & $\begin{array}{l}\text { Sandy clay } \\
\text { loam }\end{array}$ \\
\hline 2 & Type & Alluvial \\
\hline 3 & Organic matter, $\mathrm{g} \mathrm{kg}^{-1}$ & 0.57 \\
\hline 4 & Organic carbon, $\mathrm{g} \mathrm{kg}^{-1}$ & 0.38 \\
\hline 5 & Water holding capacity, $\mathrm{mm} / \mathrm{cm}$ depth of soil & 38.7 \\
\hline 6 & Cationic Exchange Capacity (CEC), $\mathrm{cmol} \mathrm{kg}^{-1}$ & 12.6 \\
\hline \multirow[t]{6}{*}{7} & Mineralogical composition: & \\
\hline & Quartzite (sand) & $40-45$ \\
\hline & Clay & $20-25$ \\
\hline & Feldspar & 15-Oct \\
\hline & Sulphides & $7-8$ \\
\hline & Sericite, Carbonates, & $23-7$ \\
\hline \multirow[t]{8}{*}{8} & Particle composition, $\%$ & \\
\hline & $>0.2 \mathrm{~mm}$ & 3 \\
\hline & $0.2 \div 0.2 \mathrm{~mm}$ & 4 \\
\hline & $0.1 \div 0.05 \mathrm{~mm}$ & 18 \\
\hline & $0.05 \div 0.02 \mathrm{~mm}$ & 10 \\
\hline & $0.02 \div 0.01 \mathrm{~mm}$ & 15 \\
\hline & $0.01 \div 0.015 \mathrm{~mm}$ & 11 \\
\hline & $<0.005 \mathrm{~mm}$ & 39 \\
\hline \multirow[t]{6}{*}{9} & $\begin{array}{l}\text { Physico-mechanical parameters of sandy } \\
\text { clay loam }\end{array}$ & \\
\hline & Natural humidity, $\%$ & $27-37$ \\
\hline & Plasticity, $\%$ & $56-61$ \\
\hline & Porosity, \% & $60-17$ \\
\hline & Coesivity factor, $\mathrm{KPa}$ & 22.46 \\
\hline & Specific weigh, $\mathrm{KN} \cdot \mathrm{m}^{-3}$ & 24.13 \\
\hline
\end{tabular}




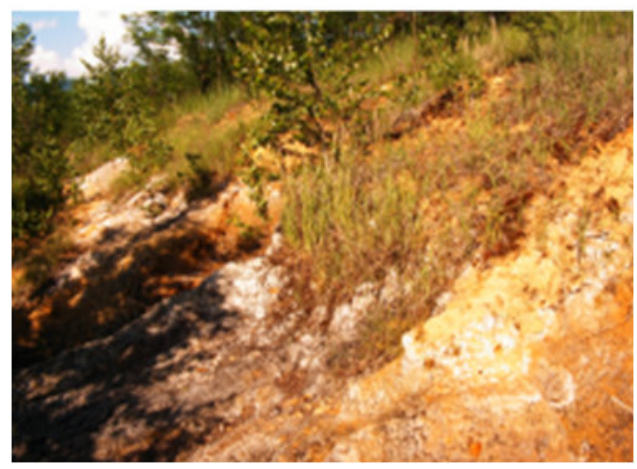

Fig. 2: Ravines in the pond's dam

The high specific area of the ore's grains induced by their low granulometry favours oxidation in the presence of air, water and microorganisms. In concentrations of $0.5-1 \%$, pyrite is the main factor that causes acidity. The next chemical reactions occur:

$$
\mathrm{FeS}_{2}+\frac{7}{2} \mathrm{O}_{2}+8 \mathrm{H}_{2} \mathrm{O} \rightarrow \mathrm{FeSO}_{4} \cdot 7 \mathrm{H}_{2} \mathrm{O}+\mathrm{H}_{2} \mathrm{SO}_{4}
$$

The rate of the reaction increases $10^{4}-10^{6}$ times in the presence of the ferooxidans bacteria ${ }^{[2]}$. Ferrous sulphate (II) is oxidised to ferric sulphate (III):

$$
\begin{aligned}
& 6 \mathrm{FeSO}_{4}+\frac{3}{2} \mathrm{O}_{2}+3 \mathrm{H}_{2} \mathrm{O} \rightarrow 2 \mathrm{Fe}_{2}\left(\mathrm{SO}_{4}\right)_{3}+2 \mathrm{Fe}(\mathrm{OH})_{3} \\
& 4 \mathrm{FeSO}_{4}+2 \mathrm{H}_{2} \mathrm{SO}_{4}+\mathrm{O}_{2} \rightarrow 2 \mathrm{Fe}_{2}\left(\mathrm{SO}_{4}\right)_{3}+2 \mathrm{H}_{2} \mathrm{O}
\end{aligned}
$$

The ferric sulphate (III) attacks the other compounds presented in the solide waste, as follows:

$$
\begin{aligned}
& \mathrm{Fe}_{2}\left(\mathrm{SO}_{4}\right)_{3}+\mathrm{FeS}_{2} \rightarrow 3 \mathrm{FeSO}_{4}+2 \mathrm{~S} \\
& 2 \mathrm{Fe}_{2}\left(\mathrm{SO}_{4}\right)_{3}+\mathrm{CuFeS}_{2} \rightarrow 5 \mathrm{FeSO}_{4}+\mathrm{CuSO}_{4}+2 \mathrm{~S} \\
& \mathrm{Fe}_{2}\left(\mathrm{SO}_{4}\right)_{3}+\mathrm{PbS} \rightarrow \mathrm{PbSO}_{4}+2 \mathrm{FeSO}_{4}+\mathrm{S} \\
& 4 \mathrm{Fe}_{2}\left(\mathrm{SO}_{4}\right)_{3}+\mathrm{ZnS}+4 \mathrm{H}_{2} \mathrm{O} \rightarrow \mathrm{ZnSO}_{4} \\
& +8 \mathrm{FeSO}_{4}+4 \mathrm{H}_{2} \mathrm{SO}_{4} \\
& \mathrm{~S}+\frac{3}{2} \mathrm{O}_{2}+\mathrm{H}_{2} \mathrm{O} \stackrel{\text { bacteria }}{\longrightarrow} \mathrm{H}_{2} \mathrm{SO}_{4}
\end{aligned}
$$

The oxidation-hydrolysis reactions are very intense at high levels of precipitations. In their absence, the oxygen in the air will oxidize the sulphide to sulphates. As the chemical reactions 1-7 indicate, the result consists in soluble $\left(\mathrm{FeSO}_{4}, \mathrm{CuSO}_{4}, \mathrm{ZnSO}_{4}\right)$ and insoluble $\left(\mathrm{PbSO}_{4}\right)$ sulphates. During rains, the acidity of waters increases following the dissolution of soluble sulphates, that are subsequently transported in the soil. Chemical reactions 1,7 and 8 indicate that large amounts of sulphuric acid are generated. If alkaline substances are present in the area (such as wastewaters coming from flotation plants, cyanuric wastewaters), partial or complete neutralization of the acidity resulting from the oxidation of the ore would occur. If the quantity of acid exceeds the quantity of alkaline substances, acidic drainage is released resulting in dissolution of heavy metals and subsequent pollution of the environment. Considering that average annual precipitation in the area $(996 \mathrm{~mm})$ exceeds evaporation (720 $\mathrm{mm})$, the acid exfiltrations appear following pond's washing by rains. Due to the low permeability of soil as the presence of sandy clay loam in the structure (Table 1), acid wastewaters accumulation is favorized at the pond's base.

Considering the above presented elements, we can conclude that, even if the active tailing ponds wouldn't be present in the studied area, the pond under the preservation is itself a threat to the environment due to its pollutant potential. Knowing that, there were some attemps to stabilized and integrate the ponds in environment, trying to cover it in vegetation, which assures inclusion of the pond in the landscape and the estetic repair of degraded land, but, the most important element is reprezented by covering and settling of toxic soils and thus avoiding their transportation by winds and their deposition over the fertile soils and human habitats in the proximity. Appearance of spontaneous vegetation on pond's dam is a long term process, the conditions of this topos, which cannot be named biotop, are extreme, the high concentrations of toxic substances (especially heavy metals) being the most drastically and limiting factor. That is why, ecological reconstruction is the only chance for greening tailing ponds.

Up to now, there were a few attemps to cover in vegetation the studied pond. Some effects are visible, but they are not enough, because the actions were focused only on one component of the ecosystem: Rebuilt of trees layer, without paying much attention to the microbiota and grass layers, the elements which are the most efficient in surface's cover and avoiding of powders mobility.

\section{MATERIALS AND METHODS}

Data regarding flora from the mining ponds from Bozanta Mare represent the results of our investigations made during 2007. The study started with a prealably 
reconnaisance of teritorry and of the chemical characteristics of the soil. For each identified species we had in attention the following features: Biological form, floristic element, number of chromosomes and the ecological indices that are characterizing them. The biological forms, number of chromosomes and floristic elements for each species are those that have been given by $V$. Ciocarlan and the values for ecological indices (T-temperature, U-humidity, R-soil $\mathrm{pH}$ ) have been established by V. Sanda, A. Popescu, M. Doltu and $N$. Donita. The used nomenclature is that adopted by Ciocarlan. For the study of vegetation we used the method of the phyto-coenological school in ZurichMontpellier, perfected by Braun-Blanque and J. Pavillard.

\section{RESULTS}

This study means to observe the specific diversity of cormphytes and fungi spontaneously installed on Bozanta pond twenty years after the attempts to revegetate the area.

Twenty years ago, on the pond dam there were planted black pine (Pinus nigra) and acacia (Robinia pseudacacia). Actual analysis of the area indicates that only a small part of them rezisted and grew (about 10-20\%), only a few have 5-10 $\mathrm{m}$ in hight and they did not cover more than $10 \%$ of pond's surface. In this situation we cannot speak about a unitary crowning as is normal in a plantation. On the $\mathrm{E}$ mountainside of the pond there are not significant differences regarding the vegetation comparing with the refference hight. Some bigger Pinus nigra and Robinia pseudacacia (5-10 $\mathrm{m}$ in hight) are presented, but their crowning projection on soil do not cover more than $5 \%$. Besides the ligneous species planted on the slopes of this pond, other vegetal individuals belonging to ligneous and herbaceous species have spontaneously installed there, species presented in the synthetic charts.

Table 2 shows some characteristic of vegetation presented on E mountainside.

The study analyzed the flora and vegetation presented on investigated tailing ponds and in the vicinity, to show the floristic differences which appear and the possible negative influences of the pond on phytocoenosis in the area. Only 11 species are present and the surface they cover is not enough. Due to the lack of the vegetal layer, ravines appear on the slopes, thus leading to the erosion of the dam under the influence of rain. The presence of ravines indicate that a great amount of soil was transported at the pond's base. In the case of E and S-E mountainsides, beyond the layer charged with heavy metals, insulation acts as a high level limiting factor making harder the development of grassy species which exploit the superficial horizon of sub-layer as water source. On S and N-W mountainsides the situation is positively different. We appreciate a lower insulation on these sides, a lower dehydration level which allows the development of a larger number of species. Some characteristics of vegetation presented on N-W mountainsides are shown in Table 3.

Raunkiaer's life forms analyses: The structure of Raunkiaer's life forms: Mega Phanerophytes (from a past forestation trying) prevail with $54.54 \%$, followed by hemicryptophytes $18.18 \%$ and the other life forms are in smaller proportions (Fig. 3).

Table 2: Characteristics of vegetation presented on $E$ and S-E mountainsides

\begin{tabular}{lllll}
\hline Survey number & 1 & 2 & 3 & 4 \\
\hline Direction & E & E & SE & SE \\
Altitude & Base & Base & The first & The first \\
& of dump & of dump & $\mathrm{v}$ & terrace \\
Trees' hight & $5-10 \mathrm{~m}$ & $5-10 \mathrm{~m}$ & $3-4 \mathrm{~m}$ & $3-5 \mathrm{~m}$ \\
Unity of crowning (degrees) & 0.6 & 0.6 & 0.4 & 0.3 \\
General cover (\%) & 20 & 20 & 15 & 10 \\
Pinus nigra & 1 & 1 & - & + \\
Robinia pseudacacia & + & + & 1 & + \\
Betula pendula & + & - & + & + \\
Frangula alnus & - & - & + & - \\
Rubus sulcatus & - & - & + & + \\
Agrostis capillaris & +-1 & + & + & 1 \\
Equisetum arvense & + & - & - & - \\
Juncus effusus & + & + & - & - \\
Cardaminopsis arenosa & + & + & - & - \\
Phragmites australis & - & - & + & - \\
Reinouttria japonica & +-1 & - & 1 & + \\
\hline
\end{tabular}

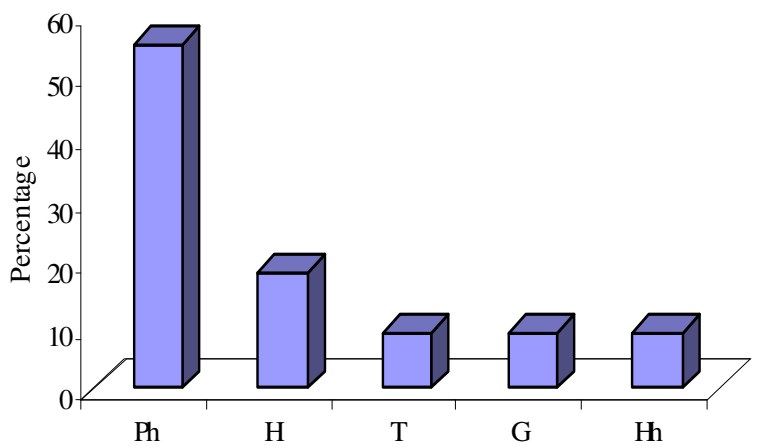

Fig. 3: Raunkiaer's life forms: PhM mega phanerophytes, Phm meso-phanerophytes, Phnnano phanerophytes, H-hemicryptophytes, Ggeophytes, Hh-helohydatophytes, chchamephytes 
Am. J. Environ. Sci., 5 (1): 116-123, 2009

Table 3: Characteristics of vegetation presented on N-W mountainsides

\begin{tabular}{|c|c|c|c|c|c|c|c|}
\hline Survey No. & 1 & 2 & 3 & 4 & 5 & 6 & 7 \\
\hline Altitude & Base & Base & $\begin{array}{l}\text { Terracy I at } \\
\text { half pond }\end{array}$ & $\begin{array}{l}\text { Terracy I at } \\
\text { half pond }\end{array}$ & $\begin{array}{l}\text { Terracy } \\
\text { II clos }\end{array}$ & $\begin{array}{l}\text { Terracy II clos } \\
\text { to upper part }\end{array}$ & $\begin{array}{l}\text { On upper } \\
\text { part of pond }\end{array}$ \\
\hline Direction & $\mathrm{N}$ & $\mathrm{N}$ & $\mathrm{N}$ & $\mathrm{N}-\mathrm{W}$ & $\mathrm{N}$ & $\mathrm{N}-\mathrm{W}$ & - \\
\hline Slope, degree & $30-40^{\circ}$ & $20^{\circ}$ & $0^{\circ}$ & $0^{0}$ & $0^{0}$ & $5^{\circ}$ & $0^{\circ}$ \\
\hline Crowning of trees & 0,3 & 0,3 & 0,3 & 0,2 & - & - & - \\
\hline Covering of grassy layer $\%$ & 60 & 50 & 10 & $5-10$ & 5 & 20 & $1-2$ \\
\hline Robinia pseudacacia & $1-2$ & +-1 & +-1 & + & - & - & - \\
\hline Populus tremula & + & + & + & + & - & - & - \\
\hline Quercus robur & + & + & - & - & + & - & - \\
\hline Betula pendula & + & + & + & + & + & - & - \\
\hline Prunus serotina & + & - & + & - & - & + & - \\
\hline Agrostis capillaris & 4 & 2 & +-1 & + & +-2 & +-1 & - \\
\hline Carex hirta & + & - & + & 2 & + & 1 & - \\
\hline Juncus effusus & + & - & - & - & - & - & - \\
\hline Juncus conglomeratus & + & - & - & - & - & - & - \\
\hline Tussilago farfara & + & + & - & - & - & - & - \\
\hline Phragmites australis & + & + & - & - & - & + & + \\
\hline Festuca rubra & + & - & - & - & - & - & - \\
\hline Holcus lanatus & + & + & - & - & + & + & - \\
\hline Solanum dulcamara & + & - & - & - & - & - & - \\
\hline Cichorium intybus & + & - & - & - & - & - & - \\
\hline Galium cruciata & + & - & - & - & - & - & - \\
\hline Lythrum salicaria & + & - & - & - & - & - & - \\
\hline Melilotus albus & + & - & - & - & - & - & - \\
\hline Verbascum phlomoides & + & - & - & - & - & - & - \\
\hline Rumex acetosa & + & - & - & + & + & - & - \\
\hline Erigeron аппииs & - & - & + & + & - & + & - \\
\hline Frangula alnus & - & + & - & + & - & - & - \\
\hline Poa pratensis & - & + & - & - & - & - & - \\
\hline Crepis biennis & - & - & + & - & - & - & - \\
\hline Rubus sulcatus & - & - & - & + & + & - & - \\
\hline Rumex acetosella & - & - & 1 & + & + & + & + \\
\hline Hieracium pilosella & - & - & - & 1 & + & + & - \\
\hline Setaria glauca & - & - & - & - & + & + & - \\
\hline Calamagrostis epigeios & - & - & - & - & - & + & - \\
\hline Convolvulus arvensis & - & - & - & - & - & + & - \\
\hline Rosa canina & - & - & + & + & - & + & - \\
\hline Polygonum aviculare & - & + & - & - & + & + & - \\
\hline Rumex crispus- & - & - & - & - & - & - & + \\
\hline
\end{tabular}

In the floristic elements spectrum, prevail the Adventive species (27.27\%), followed by the cosmopolite species and the eurasiatic species, central European species, circumpolar species and cosmopolites. The diploidy index $(\mathrm{DI}=\mathrm{D} / \mathrm{P} \times 100)$ has a value of $37.5 \%$.

Humidity indices spectrum Fig. 5 reveals the presence and preponderance of mesophytes species (37.5\%), followed by hygromesophytes $(25 \%)$. The xeromesophytes $(12.5 \%)$ and euryhygrous have both the same percentage.

Temperature indices spectrum Fig. 6 demonstrates the prevalance of mesothermophylous (37.5\%), followed by eurythermic (25\%) species and microthermophylous species $(12.5 \%)$.

Soil pH spectrum (Fig. 7) reveals the most of cormophytes species indentified on these sterile deposits tolerate varied values of this indicator.

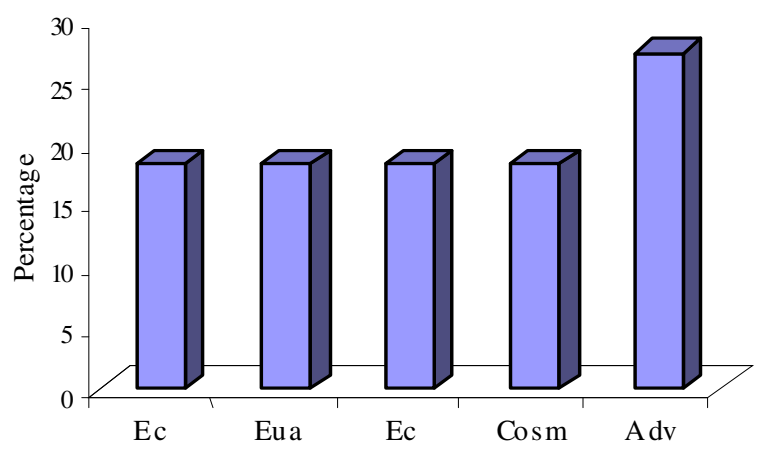

Fig. 4: Floristic elements spectrum

Prevailing of the acido-neutrophilous species (37.5\%), euriionics species (25\%) and the low acidoneutrophilous species (25\%) followed by the acidophilous species (12.5\%). 


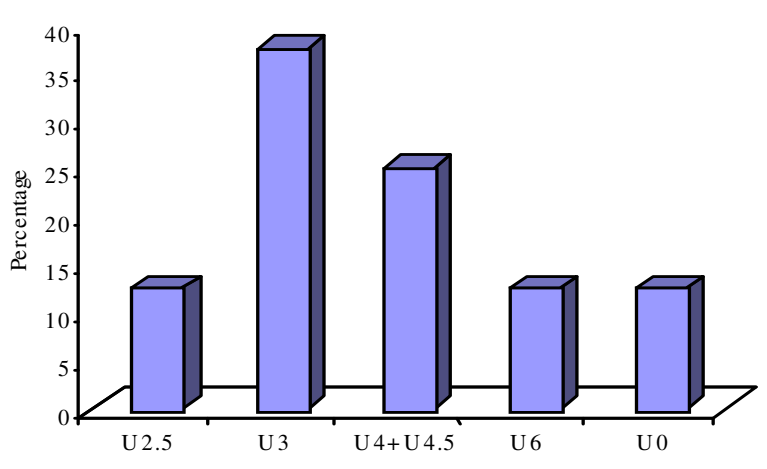

Fig. 5: Humidity indices spectrum

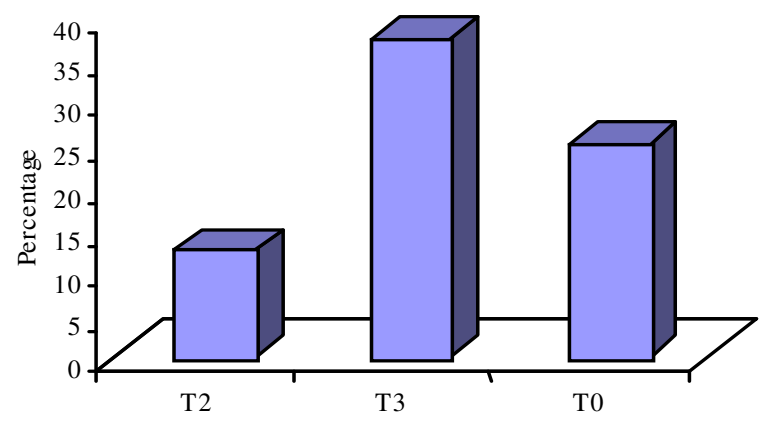

Fig. 6: Temperature indices spectrum

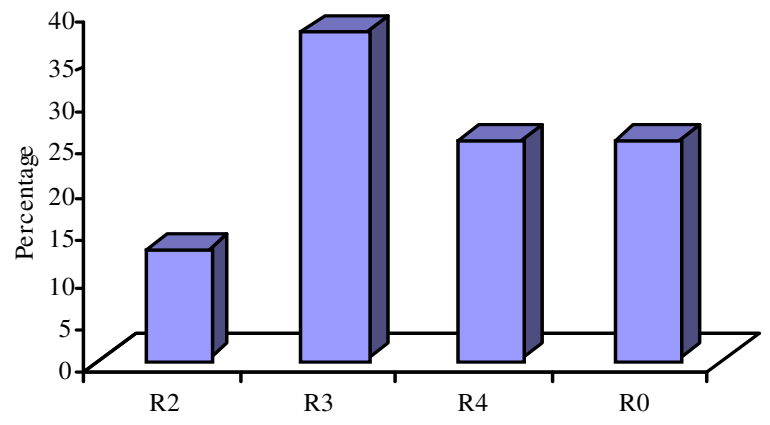

Fig. 7: Soil $\mathrm{pH}$ spectrum

It is obvious that on less exposed to the sun mountainsides, the number of species is higher, which proves that a limiting factor (as important as the sublayer) is lack of water. Also, we can notice that the surveys located at the pond's base, being in a kind of ecoton, with a soil un-washed by rains, present considerablly much more species than the mountainsides areas.

The upper part of pond's crowning is almost entirely without vegetation. The planted trees in this area are completelly dried and the grassy layer is not settled. The exception is reprezented by the water evaporation surface, with a high level of humidity where a reed (Phragmites communis) compact association is developing.

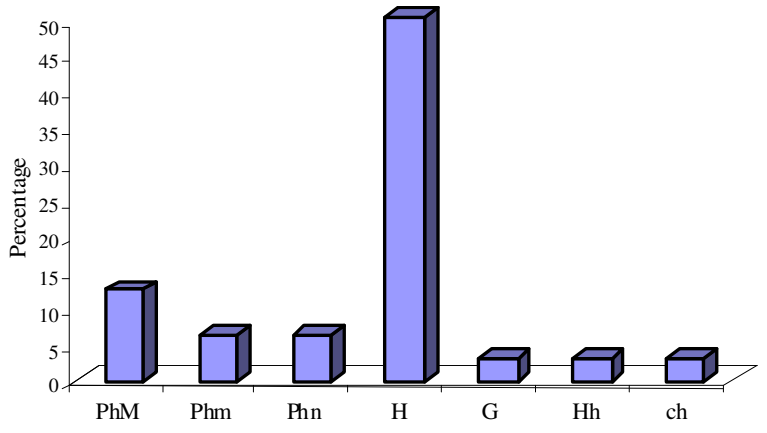

Fig. 8: Raunkiaer's life forms: $\mathrm{PhM}$ mega phanerophytes, Phm meso-phanerophytes, Phnnano phanerophytes, H-hemicryptophytes, Ggeophytes, Hh-helohydatophytes, chchamephytes

On the first terrace, at half pond and on the top some species of mushrooms like: Laccaria laccata, Scleroderma citrinum, Inocybe lacera, Xylaria hypoxylon, Suillus bovinus, Calvatia excipuliformis, Pisolithus tinctorus, Telephora terestris, Amanita muscaria, Rusula emetica, Paxillus involutus, Lactarius glyciosmus, Russula vesca were identified. We consider that mushroom diversity is considerable for this restrictive conditions. This great number of species of fungi indicate a mychorrizing maintenances with the cormophyte plants installed in such restrictive conditions.

Raunkiaer's life forms analyses: The structure of Raunkiaer's life forms: Hemicryptophytes prevail with 50 and 12.5\% represent Mega Phanerophytes (from a past forestation trying) and the other life forms are in smaller proportions Fig. 8. The great number of hemicryptophytes demonstrates the tendency of colonization of tailings by perennial herbaceous species.

In the floristic elements spectrum, prevail the Eurasiatic species (37.5\%), followed by the cosmopolite species (21.8\%) and the alien species (9.375) (Fig. 9).

The eurasiatic and circumpolar elements represents the native species background and also the main source of colonizer species.

The diploidy index (DI = D/P $\times 100)$ has a value of $33.33 \%$ reflected general ecological conditions and the pressure generated by human activities.

Humidity indices spectrum (Fig. 10) reveals the presence and preponderance of mesophytes species $(33.33 \%)$ and xeromesophytes (30\%), followed by mesohydrophylous (20\%) and euryhygrous (3.33). 


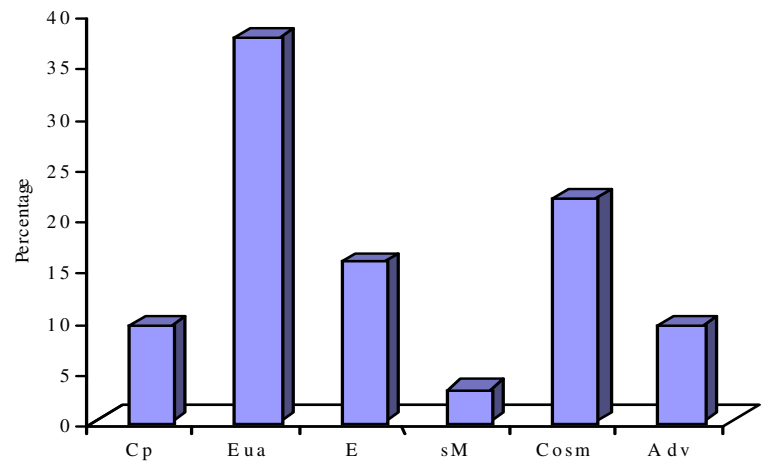

Fig. 9: Floristic elements spectrum

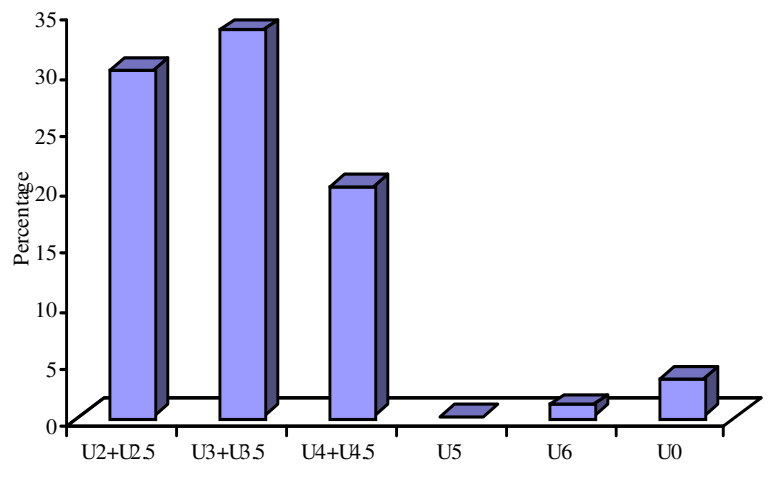

Fig. 10: Humidity indices spectrum

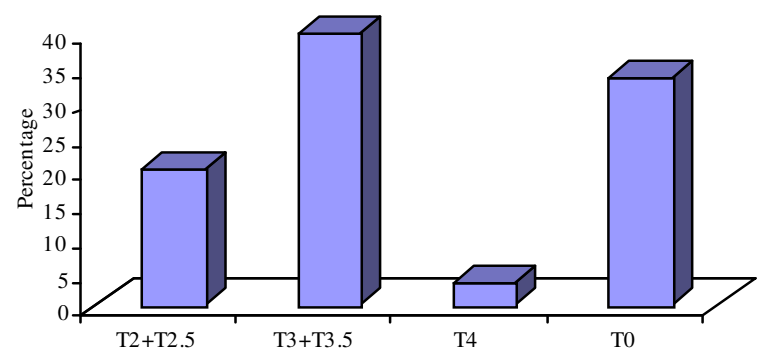

Fig. 11: Temperature indices spectrum

Temperature indices spectrum (Fig. 11) demonstrates the prevalance of mesothermophylous (36.66\%), followed by eurythermic (33.33\%) species and microthermophylous species (16.66\%).

Soil pH spectrum (Fig. 12) reveals that most of cormophytes species indentified on these sterile deposits tolerate varied values of this indicator.

Euriionics species prevail (43.33\%) and the acidoneutrophilous species have a significant proportion (23.43\%), followed by the low acido-neutrophilous species $(20 \%)$ and by the acidophilous species $(16.66 \%)$.

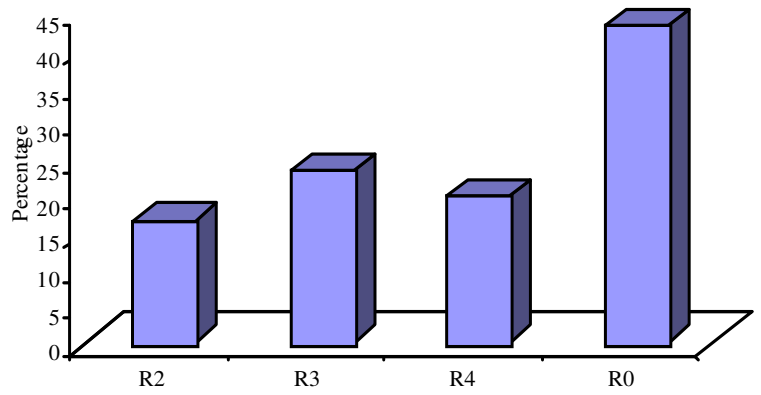

Fig. 12: Soil $\mathrm{pH}$ spectrum

The vegetation around the pond is entirely ruderal, installed along the access roads to the pond. It is obvious that high concentrations of heavy metals in soil are lower, many species being present: Daucus carota, Cichorium intybus, Trifolium pratense, Taraxacum officinale, Galium verum, Tussilgo farfara, Achillea millefolium, Campanula patula, Rumex acetoella, Galium pseudoaristatum, Eupatorium cannabinum, Equisetum arvense, Melilotus albus, Cirsium rvense, Lythrum salicaria, Ranunculus repens, Festuca giganthea, Dactylis glomerata, Lotus corniculatus, Abutilon theophrasti, Convolvulus arvensis, Galium molugo, Salix viminalis, Erigeron canadensis, Matricaria recutita, Artemisia vulgaris, Centaurea austriaca, Chrysanthemum leucanthemum, Lactuca saligna, Salix alba, Plantago lanceolata, Trifolium medium, Inula britannica, Linaria vulgaris, Lathyrus tuberosus, Thypha latifola, Silene alba, Prunus spinosa, Populus nigra.

We have noticed a low number of leguminous species whose roots could establish symbiotic relationships with settling nitrogen bacteria,meaning that the soil structure could not be improved.

\section{DISCUSSION}

The present study case catches a certain aspect of a primary sequence of vegetation, on the one hand stimulated by planting some ligneous species in order to reabilitate the area and, on the other hand, greately slowed down by the substratum's restrictive conditions.

We ascertain that on various slopes of the pond, the sequence of vegetation is at different stages, although the stratum is the same, thus proving that alongside the restrictive polluting influence of the stratum, physical agents, such as external display, insolation, erosion exert significant external influences on consolidating the vegetal layer. On the eastern slope, which is exposed to insolation and erosion, the vegetation has been in a colonisation process for over twenty years and still the number of vegetal species is small and the layer discontinuous. 


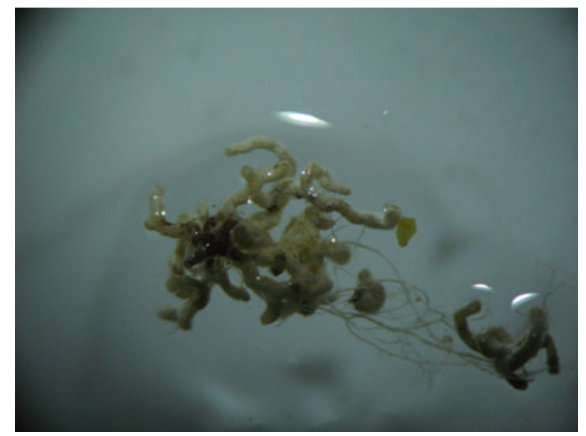

Fig. 13. Mycorrhizal roots of Quercus petraea

On the slope with a west-north-west orientation we can distinguish and determine the precise class of certain vegetal associations, the vegeal layer being in a strengthening stage. The number of species is higher, for species like: Agrostis capillaris, Carex hirta, Rumex acetosella, Hieracium pilosella, Polygonum aviculare which have more numerous and compact populations.

Moreover, many of the installed species, through planting or spontaneos reproduce vegetatively and sexed, fructifying and disseminatying. Thus, we can notice fructifying and regenerating from seedling at Pinus nigra, Prunus serotina, Quercus petreae an regeneration by vegetative means at Rubus hirtus, Hieracium pilosella.

The large number of species of mycorrhizal fungi identified on the pond indicate a maintainance of ligneous vegetation. There have also been noticed mycorrhizals at the root level of Betula verrucosa, Populus tremula, Quercus petraea (Fig. 13).

At the level of vegetation dynamics, these observations indicate a slow passage from the colonization process towards one of consolidation. Taking into consideration the restrictive conditions, this stage is a long term one and slowed down by the high concentrations of pollutants in this anthropic layer.

Stimulating the sequence stages of vegetation which condition the ecological reabilitation of such ponds, depends on abiotic factors and on the sublayer, external display, insolation, on the dip of the slopes, but also on the development and maintainance of the other categories of mycro-organisms and fungi.

Starting from the case study presented above, we consider that the ecological reconstruction by trees planting is not enough and on long term proves incapacity for covering the degraded surface with a continuous vegetation layer. Cover in vegetation of ponds should consider beyond of cover with a continuous fertile soil layer and immediatelly cover with vegetation resisting to extreme conditions of dry and high level of contaminants. The studies and rehabilitation should be also oriented to improval of microbiota (fungus, microorganisms) of which develop is directlly conditioned by the vegetation layer.

\section{CONCLUSION}

Finally, we can conclude that the tailing ponds under preservation still remain threats to the environment, due to their physically and chemically instability. One of the most important problems that must be solved concerns avoiding of soil mobility. In this respect, biological rehabilitation of the pond should be considered in all ecosystem's elements: trees and grasslayers and microbiota of soil. Simbiotic relationships settled among all these contribute not only to stop the mobility of soil, but also to improve the soil structure.

\section{ACKNOWLEDGEMENT}

We would like to acknowledge that the results presented in this study are part of the experimental data obtained in the frame of the project AMSREI-31010, funded by the CNMP-Romania.

\section{REFERENCES}

1. Bud, I., S. Duma, I. Denut, O. Benciu and O. Pintea, 2000. Tailings Ponds's Accidents. Risoprint Edn., Cluj Napoca, Romania.

2. Dudka, S. and D.C. Adriano, 1997. Environmental impacts of metal ore mining and processing: A review. J. Environ. Qual., 26: 590-602. http://jeq.scijournals.org/cgi/content/abstract/26/3/590

3. Fodor, D. and D. Baican, 2001. Impact of Mining Industry on Environment. Infomin Deva, Romania.

4. Rico, M., G. Benito and A. Díez-Herrero, 2008. Floods from tailings dam failures. J. Hazard, Mater., 154: 79-87. DOI: 10.1016/j.jhazmat.2007.09.110

5. Gautheyrou, M.P.J., 2006. Anion Exchange Capacity. Springer Berlin Heidelberg, ISBN: 9783-540-31210-9.

6. Iqbal, A., S. Hayat and J. Pichtel, 2005. Heavy Metal Contamination of Soil: Problems and Remedies. Science Publishers, Inc., Hardcover, ISBN: 1 978-1-57808-385-5, pp: 262.

7. Dexter, A.R. and K.Y. Chant, 2006. Soil mechanical properties as influenced by exchangeable cations. Eur. J. Soil Sci., 42: 219-226. DOI: 10.1111/j.1365-2389.1991.tb00403.x

8. Soukup, D.A. et al., 2008. Methods of Soil Analysis. Part 5-Mineralogical Methods. Publ. Soil Science Society of America, Inc., USA., ISBN: 978-0-89118-846-9. 